ENTREPRENEURSHIP AND SUSTAINABILITY ISSUES

ISSN 2345-0282 (online) http://jssidoi.org/jesi/

2020 Volume 8 Number 2 (December)

http://doi.org/10.9770/jesi.2020.8.2(41)
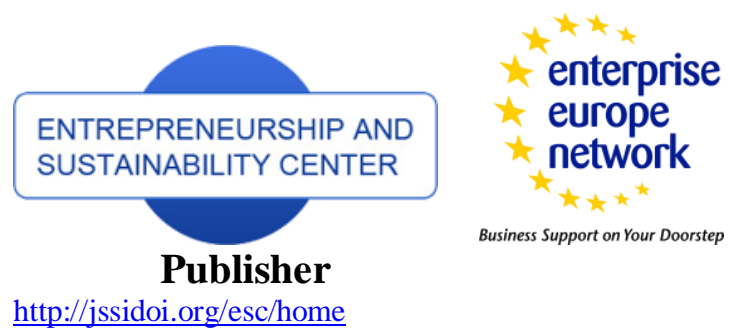

CASPA
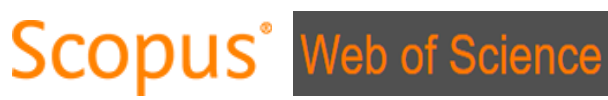

http://jssidoi.org/esc/home

1) Clarivate

Analytics

\title{
IMPACT OF R\&D EXPENDITURES ON THE COUNTRY'S INNOVATIVE POTENTIAL: A CASE
} STUDY

\author{
Ardak Nurpeisova ${ }^{1}$, Galiya Mauina ${ }^{2}$, Shakizada Niyazbekova ${ }^{3}$, Ainur Jumagaliyeva ${ }^{4}$, \\ Aigul Zholmukhanova ${ }^{5}$, Yuliya Tyurina ${ }^{6}$, Svetlana Murtuzalieva ${ }^{7}$, Leila Maisigova ${ }^{8}$ \\ ${ }^{1,2}$ Financial Academy, 25 Esenberlin street, 010000, Nur-Sultan, Kazakhstan, S.Seifullin Kazakh Agro Technical University, \\ Zhenis 62, 010000, Nur-Sultan, Kazakhstan \\ ${ }^{3}$ Moscow Witte University, 2nd Kozhukhovsky proezd 12 stroenie 1, 115432, Moscow, Russian Federation \\ ${ }^{4,5}$ S.Seifullin Kazakh Agro Technical University, Zhenis 62, 010000, Nur-Sultan, Kazakhstan \\ ${ }^{6}$ Financial University under the Government of the Russian Federation, 49, Leningradsky Prospekt, 125993, Moscow, \\ Russian Federation \\ ${ }^{7}$ Peoples' Friendship University of Russia, 6 Mikluho-Maklaya str., 117198, Moscow, Russian Federation, \\ ${ }^{7}$ Plekhanov Russian University of Economics, Stremyanny lane 36, Moscow, Russia \\ ${ }^{8}$ Ingush State University, pr. Zyazikova, 7, 386001, Magas city, Russian Federation

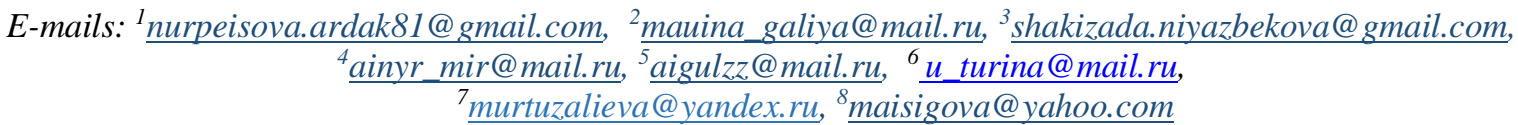

Received 25 March 2020 accepted 11 September 2020; published 30 December 2020

\begin{abstract}
Kazakhstan has all the prerequisites for the formation of innovative potential. However, to ensure the innovative economic development of Kazakhstan, it is necessary to create favorable conditions that promote the commercialization of innovations. Otherwise, all expenditures that are currently primarily of a state nature will not have the required economic indicators. The modern theory of sustainable economic growth is based on the concept of innovation. That is why the main indicators of overall economic development depend on innovative development. The article studies the variability of a data group formed from indicators of innovative development of the economy of Kazakhstan, using one of the methods of reducing dimension as a correlation analysis. The data of 2000-2018 are analyzed, that is, for 19 years. Discusses the correlation analysis of indicators characterizing the amount of research and development costs and gross domestic product. The obtained correlation coefficients demonstrate a strong linear relationship between the selected indicat ors. The statistical analysis showed: patterns of change in the GDP of the economy internal R\&D costs are almost identical, correlation-regression model of the impact of GDP on domestic R\&D expenditures. That is, the number of innovatively active enterprises and internal R\&D costs are interdependent variables with a close correlation. High correlation coefficients between the registration of patent applications and the grant of patents in Kazakhstan and the number of employees performing R\&D. A strong but negative relationship between the number of organizations performing research and development and the rest, perhaps some organizations exist only nominally and their economic activity is minimal.
\end{abstract}

Keywords: impact; correlation; relationship; GDP dynamics; economic growth; innovation 
ENTREPRENEURSHIP AND SUSTAINABILITY ISSUES

ISSN 2345-0282 (online) http://jssidoi.org/jesi/

2020 Volume 8 Number 2 (December)

http://doi.org/10.9770/jesi.2020.8.2(41)

Make your research more visible, join the Twitter account of ENTREPRENEURSHIP AND SUSTAINABILITY ISSUES: @Entrepr69728810

Reference to this paper should be made as follows: Nurpeisova, A., Mauina, G., Niyazbekova, Sh., Jumagaliyeva, A., Zholmukhanova, A., Tyurina, Yu., Murtuzalieva, S., Maisigova L. 2020. Impact of R\&D expenditures on the country's innovative potential: a case study. Entrepreneurship and Sustainability Issues, 8(2), 682-697. http://doi.org/10.9770/jesi.2020.8.2(41)

JEL Classifications: O10, O20, O30

\section{Introduction}

The study is devoted to the disclosure of the internal structure of the relationships in the data array used to assess the state of innovative development of the economy of Kazakhstan. Such work involves the statistical processing of raw data using multivariate statistical analysis methods. From a usual analysis of the dynamics of indicators, you can also get important information about the nature and patterns of data changes, but such a study, as a rule, does not provide a complete picture of the relationships.

One of the effective tools for statistical research in economics is correlation analysis, correlation analysis allows you to group the source data by the influence of external factors. That is, in essence, it is possible to create a statistical model of the problem in which the variability of all parameters is explained by the identified factors. The weight or significance of one or another factor can be estimated by the value of its share in the total variance of variables. And the close connection of each parameter of the problem with a specific factor is estimated by the correlation coefficient.

Research in the innovation sector of the economy, as a rule, comes down to an analysis of the dynamics of indicators using correlation and regression analyzes. From a usual analysis of the dynamics of indicators, you can also get important information about the nature and patterns of data changes, but such a study does not provide a complete picture of the relationships.

Of the methods of multivariate statistical analysis, the use of dimensionality reduction, as factor analysis is sometimes called, provides an opportunity to reveal the logical structure of a complex phenomenon. The main assumption of factor analysis is that phenomena in a certain field of research can be described by a relatively small number of factors. It is assumed that in the study area there is a pattern that combines the studied data into some groups.

Moreover, it is believed that each group of data has a certain factor. The term "factor" is used here in the sense of an objective reason, which unites heterogeneous data. That is, in essence, it is possible to create a statistical model of the problem in which the variability of all parameters is explained by the identified factors. The weight or significance of one or another factor can be estimated by the value of its share in the total variance of variables. And the close connection of each parameter of the problem with a specific factor is estimated by the correlation coefficient.

\section{Literature review}

Innovation is one of the most important components of the modern economy, a "stepping stone" to improving the quality of life and a sustainable, environmentally friendly future. Innovation is an important part of socioeconomic life and human life in all its manifestations. Today, there are more than a hundred different definitions and interpretations of the term "innovation". 


\section{ENTREPRENEURSHIP AND SUSTAINABILITY ISSUES}

ISSN 2345-0282 (online) http://jssidoi.org/jesi/

2020 Volume 8 Number 2 (December)

http://doi.org/10.9770/jesi.2020.8.2(41)

Make your research more visible, join the Twitter account of ENTREPRENEURSHIP AND SUSTAINABILITY ISSUES: @Entrepr69728810

In recent decades, innovation has become one of the most intensively researched topics in economics and management. World practice shows that the development of innovations is not only the main tool to increase the competitiveness of a single enterprise, but also acts as a serious incentive for the economic development of the country as a whole.

Both the current state of innovative development of the economy of Kazakhstan and the history of its development are considered in detail in many analytical works (Satpayeva, 2017; Shevyakova, Munsh, Arystan, 2019; Petrenko, Vechkinzova, Antonov, 2019; Caurkubule, Kenzhin, Bekniyazova, Bayandina, Dyussembekova, 2020). An important result of studying the state of affairs is the conclusion that the country's innovative development, being an important sector of the economy, has not yet fully realized its potential capabilities.

The works of a number of scientists are devoted to the problems of innovative development of the economy, innovative activity of industrial enterprises and the introduction of innovations: (Cohen, 2010), (Baltgailis, 2019), (Chesbrough, Vanhaverbeke \& West, 2006), (Cohen \& Levinthal, 1989), (Damanpour \& Aravind, 2012), (Denis, 2001), (Gogtay \& Thatte, 2017), (Glen, 2015), (Hauke \& Kossowski, 2011), (Murzabekova, 2010), (Niyazbekova, Grekov \& Blokhina, 2016), (Nurzhanova, Niyazbekova, Nurpeisova, Imangozhina, Satenova, 2020), (Tereliansky, 2016), (Koroteev, Terelyanskii, Ivanyuk, 2016), (Satpayeva, 2017), (Tvaronavičienė \& Razminienė 2017), (Schumpeter, 1934), (Schumpeter, 1942), (Semenyuk, Abdrashitova, Beloussova, Nechay, Listkov, Kurbatova, Niyazbekova, 2018), (Xiong, Jianmu, Wang, 2019). (Vigliarolo, 2020), (Weidlich, 2000), (Tvaronavičienè, \& Ślusarczyk, 2019), (Witt \& Zellner, 2009).

In the studies ofscientists, experts in economics and management, correlation analysis by the method of identifying the relationship, the mutual influence of various socio-economic processes.

In 1896, the correlation coefficient was first formulated and studied by Karl Pearson (Hauke \& Kossovsky, 2011), with the concepts of correlation of Francis Galton: (Hauke \& Kossovsky, 2011). Correlation analysis is used in the study of risks in the field of public and private investment management. The problems of the influence of financial markets on sustainable economic growth are investigated.

Correlation analysis is also used in the field of risk reduction associated with the management of production and company assets. Risks associated with solving organizational problems. Some scholars pay great attention to studying the correlation of the dynamics of the tourism industry and regional economic growth.

Correlation is designed to study the degree of relationship between two variables. The correlation coefficient is a measure to quantify the degree of relationship between variables. Essentially, the correlation coefficient $r$ will be in the range from -1 to +1 , i.e., $-1 \leq \mathrm{r} \leq+1$ (Hauke \& Kossovsky, 2011).

\section{Methodology}

An important component of the development of the country's economy is innovation, the level of development of which creates the basis for the sustainability of economics growth, contributes to the implementation of the strategic objectives of the territory. Innovative activity is an indicator of innovative activity. In accordance with the methodology of the Committee of Statistics of the National Economy of the Republic of Kazakhstan, innovation activity is determined by the ratio of the number of organization implementing technological, organizational, marketing innovations to the total number of organizations surveyed. Figure 1 illustrates the dynamics of innovation activity in the field of innovation in Kazakhstan for 2008-2018. 


\section{ENTREPRENEURSHIP AND SUSTAINABILITY ISSUES}

ISSN 2345-0282 (online) http://jssidoi.org/jesi/ 2020 Volume 8 Number 2 (December)

http://doi.org/10.9770/jesi.2020.8.2(41)

Make your research more visible, join the Twitter account of ENTREPRENEURSHIP AND SUSTAINABILITY ISSUES: @Entrepr69728810

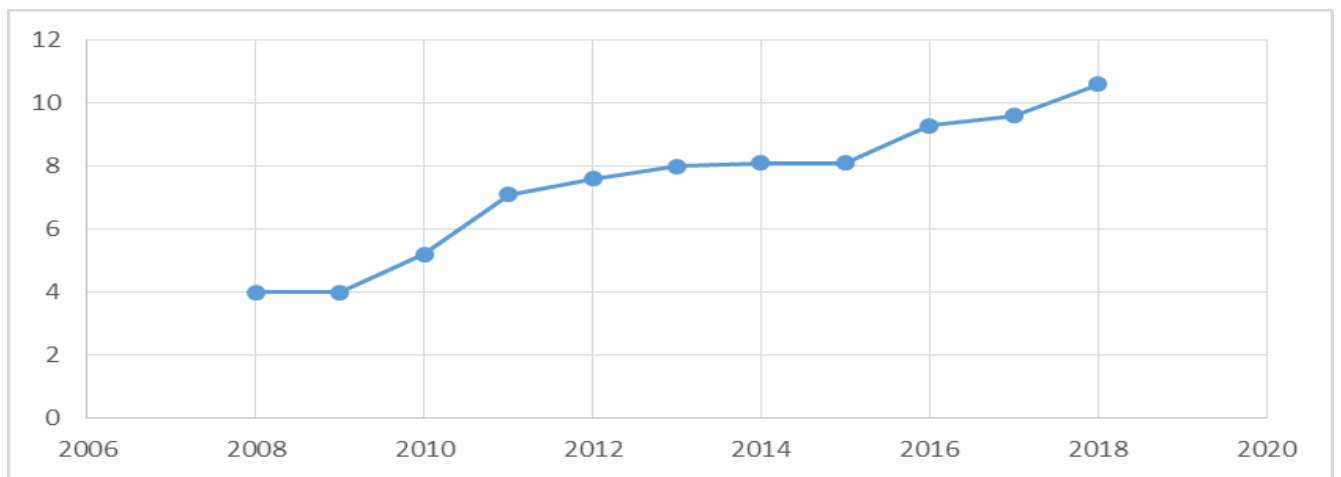

Figure 1. Level of activity in the field of innovation. Source: Committee on statistics, Ministry of national economy of the Republic of Kazakhstan

As the source of data used "Basic socio-economic indicators of the Republic of Kazakhstan for 1991-2019". The data of 2000-2018 are analyzed, that is, for 19 years. From the entire list of data on the innovative development of the country's economy, the analysis included the following indicators: a) GDP at current U.S. prices dollars, billions; b) domestics R\&D costs in dollars (Table 1).

Table 1. Indicators that characterize R \&D expenditures and GDP at current prices

\begin{tabular}{crr}
\hline & \multicolumn{2}{c}{$\begin{array}{c}\text { Internal R \& D expenditures in } \\
\text { millions of dollars }\left(\boldsymbol{X}_{i}\right)\end{array}$} \\
\hline 2000 & GDP at current prices U.S. dollars, Billions $\left(y_{i}\right)$ & 33,11616126 \\
2001 & 18,292 & 48,75357776 \\
2002 & 22,153 & 62,84512004 \\
2003 & 24,637 & 77,84128894 \\
2004 & 30,834 & 107,1728903 \\
2005 & 43,152 & 162,0063215 \\
2006 & 57,125 & 196,6841145 \\
2007 & 81,003 & 218,9800082 \\
2008 & 104,85 & 288,957606 \\
2009 & 133,442 & 264,3301695 \\
2010 & 115,309 & 227,1245334 \\
2011 & 148,047 & 295,6731687 \\
2012 & 192,626 & 350,2296962 \\
2013 & 207,999 & 405,3947282 \\
2014 & 236,635 & 364,5472527 \\
2015 & 221,416 & 374,6102703 \\
2016 & 184,388 & 195,8826471 \\
2017 & 137,289 & 220,7826923 \\
2018 & 162,887 & 220,8700306 \\
\hline Source: World Bank Open Data & 172,941 & \\
\hline
\end{tabular}


Make your research more visible, join the Twitter account of ENTREPRENEURSHIP AND SUSTAINABILITY ISSUES: @Entrepr69728810

We will find out whether there is a relationship between the indicators characterizing the costs of R\&D and the indicators of GDP.

To do this, we construct a correlation analysis between two groups of indicators: a) GDP at current U.S. prices. dollars, Billions, b) internal R\&D costs in dollars.

The correlation coefficient is estimated by the following formula:

$$
r_{x y}=\frac{\sum_{i=1}^{n}\left(x_{i}-\bar{x}\right)\left(y_{i}-\bar{y}\right)}{\sqrt{\sum_{i=1}^{n}\left(x_{i}-\bar{x}\right)^{2} \sum_{i=1}^{n}\left(y_{i}-\bar{y}\right)^{2}}}
$$

where, $x_{\tilde{i}}-$ sample data on internal research and development costs in the Republic of Kazakhstan (in dollars); $y_{i}$ - sample data on GDP at current prices (dollars); $\mathrm{n}-$ number of observations; $\bar{x}, \bar{y}-$ estimates of mathematical expectations.

Thus, the correlation coefficient for the quantities $x_{i}, y_{i}$ is:

$$
r_{x y}=\frac{\sum_{i=1}^{n}\left(x_{i}-\bar{x}\right)\left(y_{i}-\bar{y}\right)}{\sqrt{\sum_{i=1}^{n}\left(x_{i}-\bar{x}\right)^{2} \sum_{i=1}^{n}\left(y_{i}-\bar{y}\right)^{2}}}=0.9380
$$

Thus, the correlation value is 0.9380 . This means that $x_{i}, y_{i}$ there is a fairly close linear relationship between the variables, and on the basis of research it can be concluded that innovative development is highly dependent on the use and implementation of highly efficient technologies and the latest developments, as well as the development of science and technology.

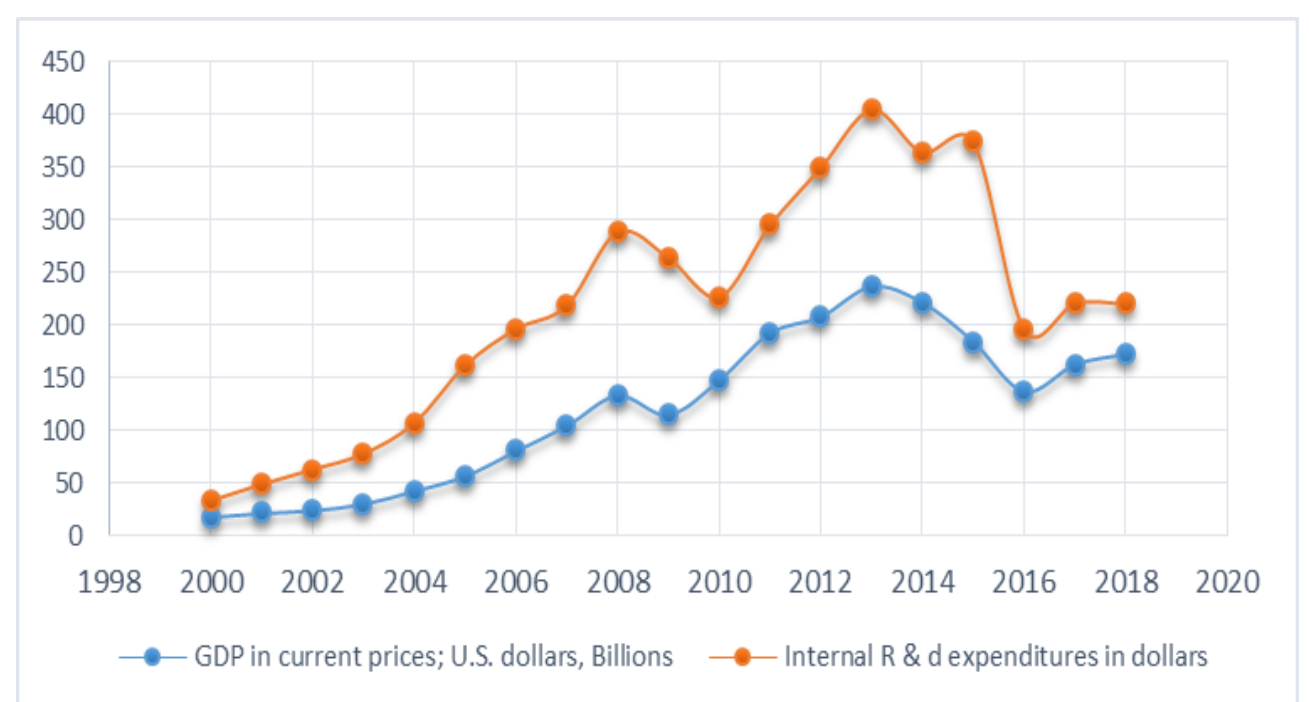

Figure 2. Indicators that characterize the introduction of innovations in the economy of the Republic of Kazakhstan.

Figure 2 shows graphs of changes in GDP at current prices, as well as domestic R\&D costs (in dollars). From a visual inspection of the graphs it can be seen that the patterns of change in the GDP of the economy and the internal costs of $R \& D$ are almost identical. 
Make your research more visible, join the Twitter account of ENTREPRENEURSHIP AND SUSTAINABILITY ISSUES: @Entrepr69728810

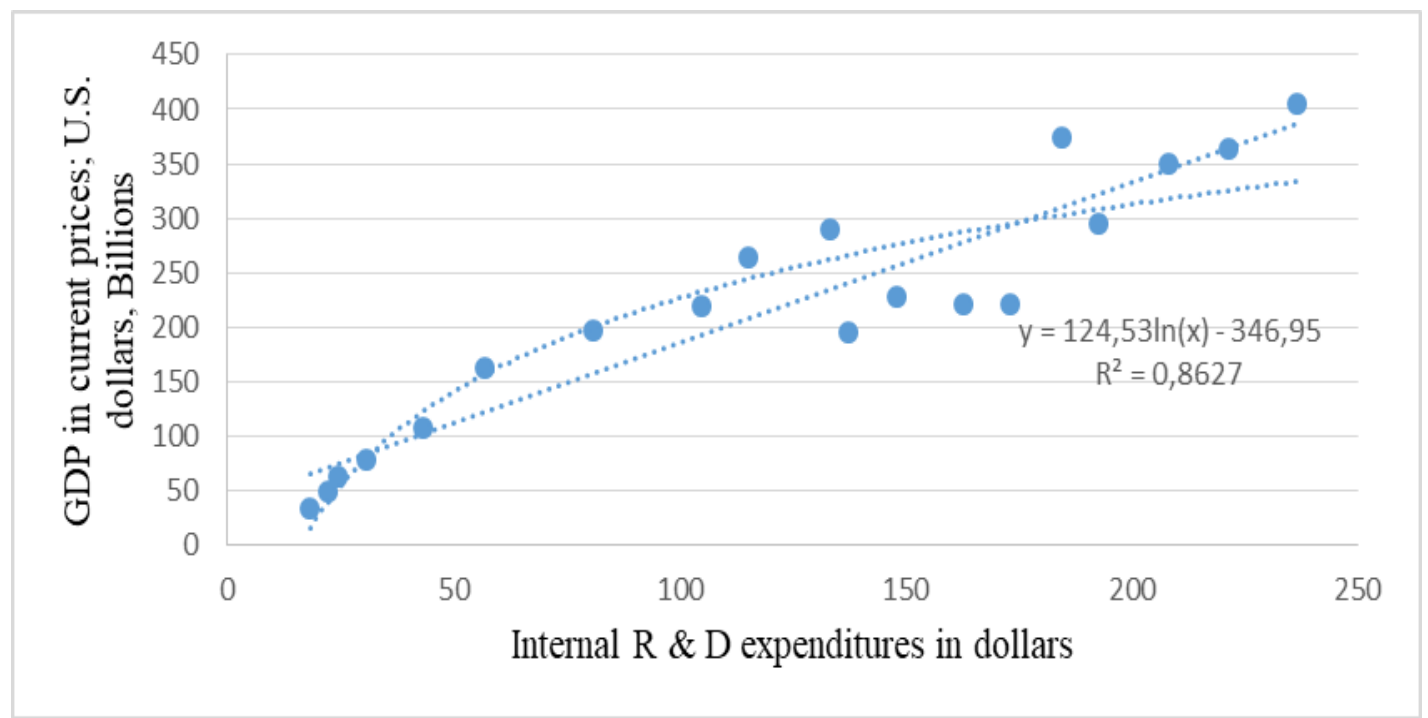

Figure 3. Correlation and regression model of the impact of GDP on domestic R \& d expenditures.

The calculated correlation and regression model shows a strong positive effect of GDP on domestic R\&D expenditures (Figure 3).

Figure 3 shows a comprehensive statistical method for spot forecasting a system of economic indicators. The main features of this method are:

1. The method allows in a complex to consider a variety of useful information about the forecasted system of economic indicators: trends in indicators over time, statistical patterns of relationships between indicators, balance ratios, etc.

2. When making predictive calculations of economic indicators using the integrated method, you can simultaneously use an arbitrary number of private statistical models for each forecast indicator. Between themselves, these models can differ in the number and composition of the independent factors of the economic process that enter into them, the structure of the relationship between the dependent and independent variables of the external and internal environment of the organization.

To identify the best trend equation of the analyzed time series, we determine the parameters of the following main types of trends: linear, parabolic, power-law, exponential, hyperbolic. The results of these calculations are shown below:

1. Linear finction

$$
\mathrm{y}=1.4705 x+39.003 ; \quad \mathrm{R}^{2}=0.8799
$$

2. Logarithmic function

$$
\mathrm{y}=124.53 \ln (x)-346.95 ; \quad \mathrm{R}^{2}=0.8627
$$

3. Power function

$$
\mathrm{y}=4.1931 x^{0.928} ; \quad \mathrm{R}^{2}=0.9322
$$

4. Exponential function

$$
\mathrm{y}=60.287 e^{0.009} ; \quad \mathrm{R}^{2}=0.7975
$$


ENTREPRENEURSHIP AND SUSTAINABILITY ISSUES

ISSN 2345-0282 (online) http://jssidoi.org/jesi/ 2020 Volume 8 Number 2 (December)

http://doi.org/10.9770/jesi.2020.8.2(41)

Make your research more visible, join the Twitter account of ENTREPRENEURSHIP AND SUSTAINABILITY ISSUES: @Entrepr69728810

The calculated correlation and regression model show a strong positive effect of GDP on domestic R\&D expenditures (Figure 3). The highest values of the exponent $\mathrm{R}^{2}$ correspond to nonlinear functions, like the logarithmic function $\left(R^{2}=0.8627\right)$ and the exponential function $\left(R^{2}=0.795\right)$.

\section{Application functionality}

In this section, we consider the innovative activity of Kazakhstan enterprises in all types of innovations. The full use of innovations for national development is possible only if a targeted innovation policy is carried out at the state level. This task is especially relevant for Kazakhstan, which has significant innovative potential, which is clearly used insufficiently. Thus, the level of innovative activity of enterprises, despite the growth from 9.3 in 2016 to 9.6 in 2017 and in 2018, reached only 10.6. The number of enterprises with innovations decreased from 421 in 2008 to 384 in 2018.

The innovative activity of Kazakhstan enterprises in all types of innovations in 2018 was characterized as follows. Of the 30,501 respondents, only 3,230 were innovation-active, that is, the level of activity in the field of innovation was only $10.6 \%$. The enterprises of the Republic of Kazakhstan by type of innovation are divided into the following:

- product innovations;

- process;

- marketing;

- organizational innovation.

In 2018, out of 3,230 innovation-active enterprises, 863 had product innovations, 1,530 had process innovations, 700 had marketing innovations, 1,082 had organizational innovations, and only 37 had all four types of innovations. The innovative activity of enterprises in product and process innovations does not have a pronounced upward trend. If in 2008 the level of activity of enterprises in this area was $4.0 \%$, then in 2018 it increased to $10.6 \%$.

Kazakhstani enterprises do not seek to research and development independently and are not inclined to invest in the creation of new products. One of the problems of innovative development in Kazakhstan is the incompleteness of scientific research, its separation from production, as the applied developments are not continued in the form of commercialization and implementation in production. In order to solve this problem, Kazakhstan has adopted a number of Programs, created Institutes, adopted Laws. An important role in this is given to the development of innovative entrepreneurship capable of quickly establishing high-tech products.

In the Republic of Kazakhstan, 384 organizations were engaged in research and development in 2018 (386 organizations in 2017).So in 2018, in terms of the number of innovatively active enterprises, the three leaders were: Almaty - 135 enterprises, Nur-Sultan - 60 enterprises, East Kazakhstan region - 35 enterprises.

At the same time, the smallest number of innovation-active ones according to the results of 2018 was demonstrated by Mangistau region - 6 enterprises, North Kazakhstan region -5 enterprises (Table 2). 
ENTREPRENEURSHIP AND SUSTAINABILITY ISSUES

ISSN 2345-0282 (online) http://jssidoi.org/jesi/ 2020 Volume 8 Number 2 (December)

http://doi.org/10.9770/jesi.2020.8.2(41)

Make your research more visible, join the Twitter account of ENTREPRENEURSHIP AND SUSTAINABILITY ISSUES: @Entrepr69728810

Table 2. Number of organizations performing research and development in the regions of Kazakhstan

\begin{tabular}{llllll}
\multicolumn{1}{c}{ Table 2. Number of organizations performing research and development in the regions of Kazakhstan } \\
\hline & 2014 & 2015 & 2016 & 2017 & 2018 \\
& & & & & \\
\hline Republic of Kazakhstan & 392 & 390 & 383 & 386 & 384 \\
Akmola & 11 & 11 & 9 & 11 & 11 \\
Aktobe & 14 & 14 & 14 & 16 & 16 \\
Almaty & 13 & 11 & 10 & 11 & 9 \\
Atyrau & 9 & 10 & 11 & 10 & 10 \\
West Kazakhstan & 9 & 7 & 8 & 8 & 10 \\
Zhambyl & 11 & 11 & 11 & 11 & 9 \\
Karaganda & 31 & 32 & 33 & 29 & 28 \\
Kostanay & 13 & 14 & 13 & 14 & 12 \\
Kyzylorda & 6 & 8 & 10 & 8 & 7 \\
Mangystau & 7 & 5 & 7 & 6 & 6 \\
Pavlodar & 11 & 9 & 10 & 11 & 14 \\
North Kazakhstan & 3 & 4 & 5 & 5 & 5 \\
Turkestan & 5 & 4 & 5 & 6 & 6 \\
East Kazakhstan & 30 & 30 & 35 & 34 & 35 \\
Nur-Sultan & 59 & 53 & 55 & 62 & 60 \\
Almaty & 148 & 152 & 133 & 131 & 135 \\
Shymkent & 12 & 15 & 14 & 13 & 11 \\
\hline Source: Ministry of National Economy of the RK, committee of statistics, information for 2019 & \\
\hline
\end{tabular}

The highest level of innovative activity of enterprises was observed in the East Kazakhstan region - 15.5\%, which is almost 1.5 times higher than the republican indicator. Next come the cities of Nur-Sultan and the cities of Karaganda, the cities of Kyzylorda $-14.7 \%, 14.7$ and 12.2\%, respectively. The lowest indicators of innovative activity of enterprises in the Mangistau region are $4.0 \%$ (Figure 4).

Analysis of statistical data on the innovative development of the regions of Kazakhstan allows us to distinguish three groups of regions of the Republic of Kazakhstan by the level of innovative activity:

- with a low level: Mangistau, Turkestan, West Kazakhstan;

- with an average level: Kostanay, Kyzylorda, North Kazakhstan, etc.;

- with a high level: East Kazakhstan region, the city of Nur-Sultan and Karaganda region.

The Republic of Kazakhstan is characterized by significant differences in the level of innovative potential of the regions, while the innovative capabilities of most areas can be rated as average.

In the modern world, transport services provide an increase in the efficiency of social production, the normal functioning of the economy. The issue of introducing innovations in the transport sector of Kazakhstan is of great relevance, since it is here that conditions are created for the rational distribution of production forces across the country, taking into account the most appropriate approach to production consumption areas and sources of raw 
Make your research more visible, join the Twitter account of ENTREPRENEURSHIP AND SUSTAINABILITY ISSUES: @Entrepr69728810

materials for enterprises of various sectors of the economy, which allows such industries as agriculture to develop, trade and the rest.

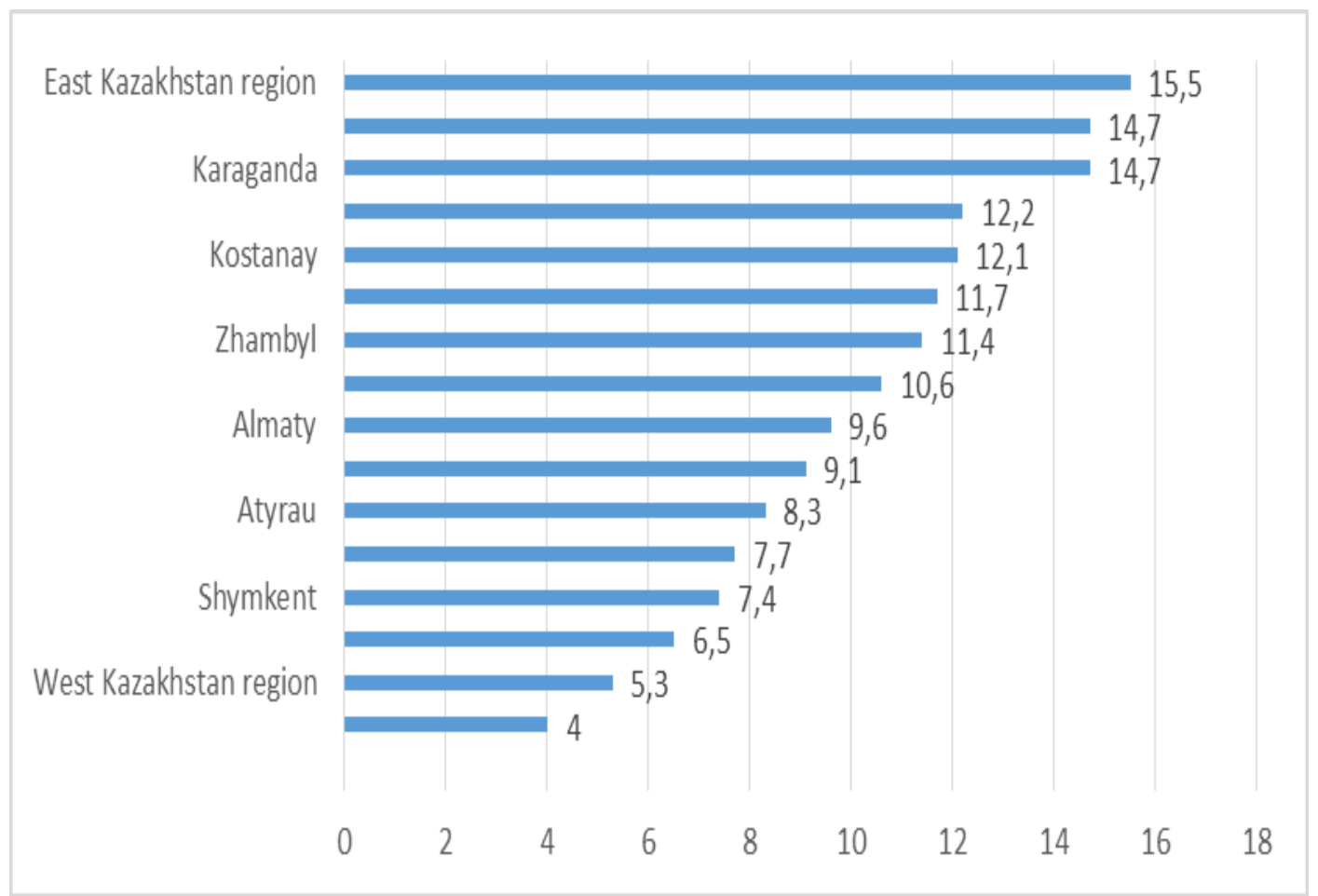

Figure 4. The level of innovation activity of enterprises for all types of innovations in 2018.

The expenditures of Kazakhstan for research and development (R\&D) averaged 0, $1 \%$ of GDP, while on the recommendation of UNESCO, developing countries need to bring R\&D expenditures to 1\% of GDP. Currently, the share of scientific research in the EU countries is on average 1.8 percent of European GDP, it is planned to bring this indicator to 4 percent.

This indicator is in Finland - 3.49\%, Korea - 3.64\%, USA - 2.6\%, China - 1.44\% of the country's gross domestic product, and on average in the countries of the Organization for Economic Cooperation and Development - 2, $24 \%$.

In comparison with the data for Kazakhstan, this suggests that financial support for research and development remains a weak link in Kazakhstan's innovation policy. For comparison, it should be noted that in developed countries, the expenditures of the business sector significantly exceed government spending on $\mathrm{R} \& \mathrm{D}$, since fundamental research is traditionally carried out in the public sector, and the business sector is engaged in applied research. 


\section{ENTREPRENEURSHIP AND SUSTAINABILITY ISSUES}

ISSN 2345-0282 (online) http://jssidoi.org/jesi/ 2020 Volume 8 Number 2 (December)

http://doi.org/10.9770/jesi.2020.8.2(41)

Make your research more visible, join the Twitter account of ENTREPRENEURSHIP AND SUSTAINABILITY ISSUES: @Entrepr69728810

Table 3. Introduction of innovations in the economy of the Republic of Kazakhstan

\begin{tabular}{|c|c|c|c|c|c|c|c|c|c|}
\hline Main indicators & 2010 & 2011 & 2012 & 2013 & 2014 & 2015 & 2016 & 2017 & 2018 \\
\hline $\begin{array}{l}\text { Domestic expenditures } \\
\text { on research and } \\
\text { development, million } \\
\text { tenge }\end{array}$ & 33466,8 & 43351,6 & 51253,1 & 61672,7 & 66347,6 & 69302,9 & 66600,1 & 68884,2 & 72224,5 \\
\hline GDP as a percentage & 0,15 & 0,15 & 0,16 & 0,17 & 0,17 & 0,17 & 0,14 & 0,13 & 0,12 \\
\hline $\begin{array}{l}\text { The number of } \\
\text { organizations in which } \\
\text { R \& D units }\end{array}$ & 424 & 412 & 345 & 341 & 392 & 390 & 383 & 386 & 384 \\
\hline $\begin{array}{l}\text { Number of employees } \\
\text { performing } R \& D \text {, } \\
\text { people }\end{array}$ & 17021 & 18003 & 20404 & 23712 & 25793 & 24735 & 22985 & 22081 & 22378 \\
\hline $\begin{array}{l}\text { Among them are } \\
\text { specialists-researchers }\end{array}$ & 10870 & 11488 & 13494 & 17195 & 18930 & 18454 & 17421 & 17205 & 17454 \\
\hline Doctor of science & 1341 & 1246 & 1065 & 1688 & 2006 & 1821 & 1828 & 1818 & 1740 \\
\hline $\begin{array}{l}\text { Doctor of philosophy } \\
\text { PhD }\end{array}$ & 59 & 95 & 131 & 218 & 330 & 431 & 456 & 589 & 856 \\
\hline $\begin{array}{l}\text { Research and } \\
\text { development }\end{array}$ & 103571 & 121395 & 148530 & 153567 & 171626 & 184940 & 208752 & 228385 & 240717 \\
\hline
\end{tabular}

A quantitative approach to assessing innovative potential involves the analysis of a system of statistical indicators that reflect the dynamics of the development of the scientific and innovative sphere. In the Republic of Kazakhstan in recent years, the costs of research and development have steadily increased in comparable prices. Figure 5 presents the dynamics of the main indicators of the state and development of science in Kazakhstan for 2010-2018. 
Make your research more visible, join the Twitter account of ENTREPRENEURSHIP AND SUSTAINABILITY ISSUES: @Entrepr69728810

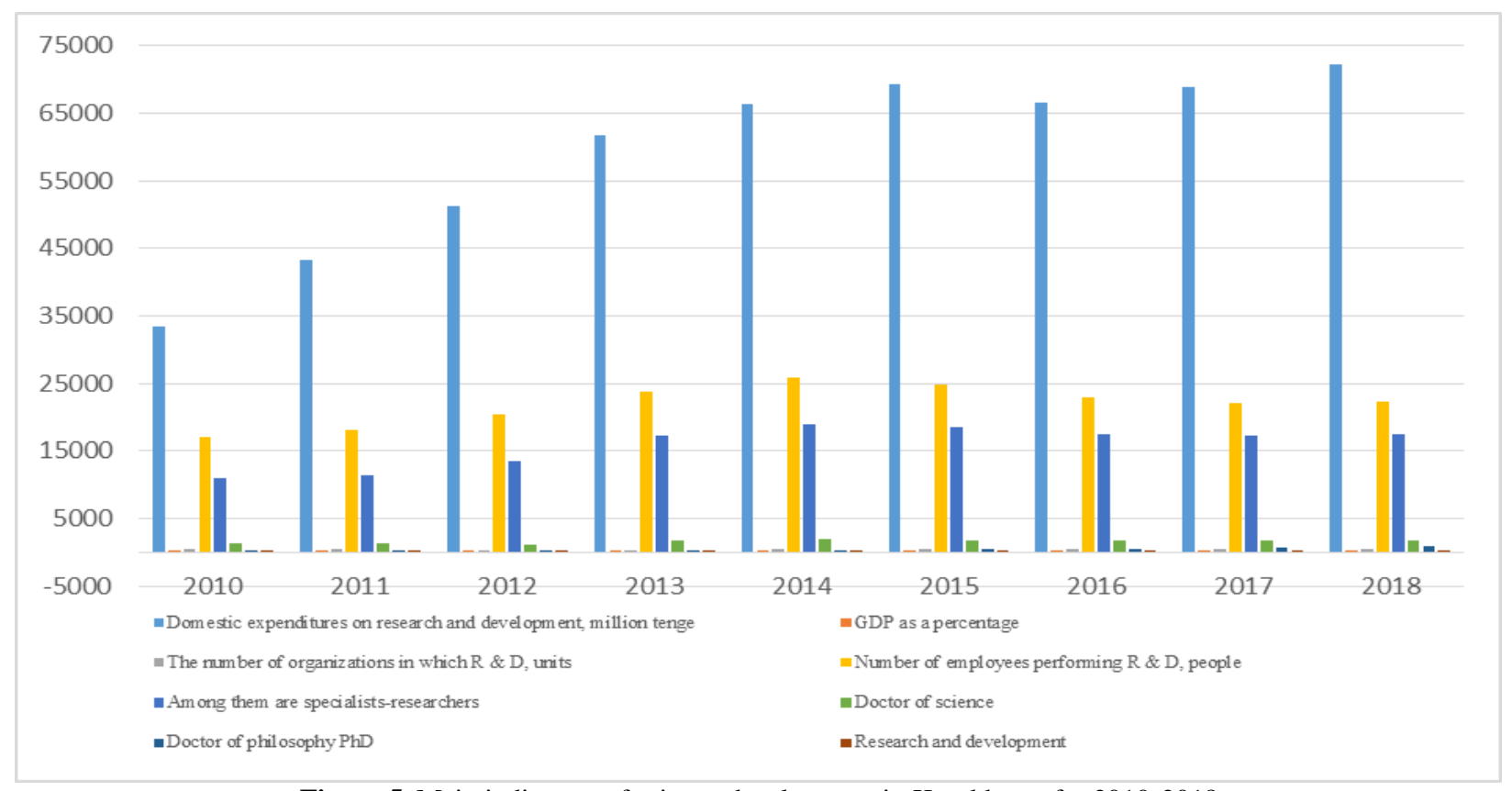

Figure 5. Main indicators of science development in Kazakhstan for 2010-2018

Let us consider the dependencies of the key factors of the innovative development of the Kazakhstan economy, including:

- number of employees performing $\mathrm{R} \& \mathrm{D}$, by ownership of organizations, thousand people;

- number of innovatively active enterprises, units;

- domestic R\&D costs, mln tenge;

- domestic R\&D costs from the public sector, mln tenge;

- $\quad$ share of innovative products (goods, services) to GDP;

- costs of technological innovation of enterprises by ownership, mln tenge;

- registration of trademarks and service marks;

- number of organizations performing research and development, units;

- research and development.

Of interest is the value of the pair correlation coefficient between v2 and v3: 0.96. That is, the number of innovatively active enterprises and internal $R \& D$ costs are interdependent variables with a close correlation. Finding a correlation between the costs of technological innovation and the share of innovative products in GDP showed that the relationship is positive, but not strong: 0.41 .

The high correlation coefficients between the registration of patent applications and the grant of patents in Kazakhstan and the number of employees performing $R \& D$, internal $R \& D$ expenditures, and the share of innovative products in GDP $(r=0.95, r=0.78, r=0.81)$ indicates the fact that the country has a favorable economic situation and an increase in the intensity of state regulation leads to an increase in scientific activity. 
Make your research more visible, join the Twitter account of ENTREPRENEURSHIP AND SUSTAINABILITY ISSUES: @Entrepr69728810

Let us analyze the above data on the introduction of innovations in the economy. The calculation results are shown in Table 4, which presents a matrix of correlation coefficients.

In order to analyze the interconnections between the GDP indicators, table 4 shows the paired correlation coefficients.

Table 4. Correlation matrix of indicators that characterize the introduction of innovations in the economy of the Republic of Kazakhstan

\begin{tabular}{|c|c|c|c|c|c|c|c|c|c|c|}
\hline Variables & & $\mathrm{v} 1$ & v 2 & v 3 & $\mathrm{v} 4$ & v 5 & $\mathrm{v} 6$ & v 7 & $\mathrm{v} 8$ & v 9 \\
\hline $\begin{array}{l}\text { Number of employees who performed R \& } \\
D \text {, by form of ownership of organizations, } \\
\text { thousand people. }\end{array}$ & v 1 & 1,00 & 0,80 & 0,91 & 0,81 & 0,73 & 0,62 & 0,95 & $-0,87$ & 0,76 \\
\hline $\begin{array}{l}\text { Number of innovative-active enterprises, } \\
\text { units }\end{array}$ & v 2 & & 1,00 & 0,96 & 0,84 & 0,72 & 0,87 & 0,87 & $-0,60$ & 0,98 \\
\hline $\begin{array}{l}\text { Domestic expenditures on research and } \\
\text { development, million tenge }\end{array}$ & v 3 & & & 1,00 & 0,90 & 0,77 & 0,78 & 0,94 & $-0,75$ & 0,94 \\
\hline $\begin{array}{l}\text { Internal } \mathrm{R} \& \mathrm{D} \text { expenditures from the public } \\
\text { sector, million tenge }\end{array}$ & v 4 & & & & 1,00 & 0,70 & 0,65 & 0,78 & $-0,78$ & 0,83 \\
\hline $\begin{array}{l}\text { Share of innovative products (goods, } \\
\text { services) to GDP } \\
\text { Expenditures on technological innovations of } \\
\text { enterprises by ownership forms, million } \\
\text { tenge }\end{array}$ & v 5 & & & & & 1,00 & 0,41 & 0,81 & $-0,75$ & 0,75 \\
\hline $\begin{array}{l}\text { Registration of trademarks and service marks } \\
\text { and granting of patents }\end{array}$ & v 7 & & & & & & & 1,00 & $-0,81$ & 0,86 \\
\hline $\begin{array}{l}\text { Number of organizations that performed } \\
\text { research and development, units }\end{array}$ & v 8 & & & & & & & & 1,00 & $-0,59$ \\
\hline Research and development & v 9 & & & & & & & & & 1,00 \\
\hline
\end{tabular}

A strong but negative relationship between the number of organizations performing research and development and the rest $(r=-0.87, r=-0.75, r=-0.81, r=-0.78)$, perhaps some organizations exist only nominally and their economic activity is minimal.

As is known, the pair correlation coefficient shows the degree of tightness of the relationship between only two variables under the indirect influence of other variables. That is, correlation analysis does not provide a complete picture of the relationships between variables.

The state as a whole supports the implementation of scientific developments of innovative implementations. This is confirmed by an increase in the real value of domestic research costs from the state budget. Despite the increase in state budget revenues, the number of organizations performing research and development is declining.

\section{Conclusions}

The analysis included: the number of employees performing R\&D, by ownership of organizations; number of innovatively active enterprises; internal $R \& D$ costs; domestic $R \& D$ costs from the public sector; share of innovative products (goods, services) to GDP; costs of technological innovation of enterprises by ownership; 


\section{ENTREPRENEURSHIP AND SUSTAINABILITY ISSUES}

ISSN 2345-0282 (online) http://jssidoi.org/jesi/ 2020 Volume 8 Number 2 (December)

http://doi.org/10.9770/jesi.2020.8.2(41)

Make your research more visible, join the Twitter account of ENTREPRENEURSHIP AND SUSTAINABILITY ISSUES: @Entrepr69728810

registration of trademarks and service marks; number of organizations performing research and development; number of scientific developments.

Thus, the statistical analysis showed:

- correlation analysis between two groups of indicators: a) GDP at current U.S. prices. dollars, Billions, b) internal R\&D costs in dollars. The analysis showed that the patterns of change in the GDP of the economy in the period 2000-2018. domestic R\&D costs are almost identical (0.7393);

- correlation-regression model of the impact of GDP on domestic R\&D expenditures; the calculated correlation-regression model shows a strong positive effect of GDP on domestic expenditures on R\&D;

- correlation matrix of indicators characterizing the introduction of innovations in the economy of the Republic of Kazakhstan. The analysis showed that between the pair correlation coefficients v2 and v3 is 0.96. That is, the number of innovatively active enterprises and internal $R \& D$ costs are interdependent variables with a close correlation;

- also in the study of indicators characterizing the introduction of innovations in the economy of the Republic of Kazakhstan, the relationship between the costs of technological innovation and the share of innovative products to GDP showed that the relationship is positive, but not strong: 0.41 ;

- high correlation coefficients between registration of patent applications and the grant of patents in Kazakhstan and the number of employees performing R\&D in the period 2000-2018. domestic expenditures on R\&D, the share of innovative products in GDP $(r=0.95, r=0.78, r=0.81)$;

- a strong but negative relationship between the number of organizations that performed research and development and the rest $(r=-0.87, r=-0.75, r=-0.81, r=-0.78)$, perhaps some organizations exist only nominally and their economic activity is minimal.

Thus, based on the analysis, it is possible to formulate an innovation policy is an important, but not the only tool for managing GDP growth, which proves the research conducted in this article. Many studies of the impact of innovation on GDP dynamics show that the level of interconnection between innovation and the economic development of different countries varies.

The results of the study show that the country has a positive relationship between GDP growth and R\&D expenditures. Analyzing the relationship between GDP growth dynamics and innovation variables in Kazakhstan, in most cases, one can observe a rather weak association of innovations and economic development. Certain measures were proposed that should be taken by the Kazakh authorities to stimulate innovation and economic growth. Based on the experience of technologically developed countries, the Kazakh government offers promising innovative policy measures to stimulate economic growth. It is important to ensure the proper level of growth in costs for technological innovations in order to enhance autonomy in Kazakhstan.

\section{References}

Baltgailis, J. 2019. The issues of increasing the effectiveness of teaching comparative economics. Insights into Regional Development, 1(3), 190-199. https://doi.org/10.9770/ird.2019.1.3(1)

Caurkubule, Zh. L., Kenzhin, Zh. B. Bekniyazova, D.S., Bayandina, G.D., Dyussembekova, G. S. 2020. Assessment of competitiven ess of regions of the Republic of Kazakhstan. Insights into Regional Development, 2(1), 469-479. http://doi.org/10.9770/IRD.2020.2.1(6)

Chesbrough, H. W., Vanhaverbeke, W., \& West, J. (Eds.). (2006). Open Innovation. Researching a New Paradigm. Oxford: Oxford University Press. 


\section{ENTREPRENEURSHIP AND SUSTAINABILITY ISSUES}

ISSN 2345-0282 (online) http://jssidoi.org/jesi/ 2020 Volume 8 Number 2 (December)

http://doi.org/10.9770/jesi.2020.8.2(41)

Make your research more visible, join the Twitter account of ENTREPRENEURSHIP AND SUSTAINABILITY ISSUES: @Entrepr69728810

Cohen, W. M. (2010). Fifty years of empirical Studies of innovative activity and performance. In B. W. Hall \& N. Rosenberg (Eds.), Handbook of the economics of innovation (pp. 129-213). Amsterdam: Elsevier.

Cohen, W. M., \& Levinthal, D. A. (1989). Innovation and learning: the two faces of R\&D. Econ J, 99, 569-596.

Damanpour, F., \& Aravind, D. (2012). Managerial innovation: conceptions, processes, and antecedents. Management and Organization Review, 8, 423-454.

Denis, J. D. (2001), The origins of correlation and regression: Francis Galton or Auguste Bravais and the error theorists? History and Philosophy of Psychology Bulletin, 13, pp. 36-44.

Glen, S. (2015), Multicollinearity: Definition, Causes, Examples, https://www.statisticshowto.datasciencecentral.com/multicollinearity/

Gogtay, N. J. and Thatte, U. M. (2017), Principles of correlation Analysis, Journal of The Association of Physicians of India, 65 (March), pp. 78-81.

Hauke, J., Kossowski, T. (2011), Comparison of values of Pearson's and Spearman's correlation coefficients on the same sets of data, Questiones Geographicae, 30(2), pp. 87-93 http://dx.doi.org/10.2478/v10117-011-0021-1

Koroteev, M., Terelyanskii, P.V., Ivanyuk, V.A. (2016). Arithmetic of Fuzzy Numbers in Generalized Trapezoidal Form. Journal of Mathematical Sciences. Journal of Mathematical Sciences, 216(5) http://dx.doi.org/10.1007/s10958-016-2931-x

Murzabekova, G. Y. (2010). Exhausters and implicit functions in nonsmooth systems, optimization. A Journal of Mathematical Programming and Operations Research, 59(1), 105-113

Niyazbekova, Sh. U., Grekov, I.E., Blokhina, T.K. (2016), The influence of macroeconomic factors to the dynamics of stock exchange in the Republic of Kazakhstan. Economy of region, 12(4), 1263-1273. http://dx.doi.org/10.17059/2016-4-26

Nurzhanova, G. I., Niyazbekova Sh. U., Nurpeisova, A. A, Imangozhina, Z A., Satenova. D. E. (2020), Youth labor Market Analysis and Assessment of the Republic of Kazakhstan. International Scientific Conference "Far East Con" (ISCFEC 2020)

, 17 March, 360-366, https://doi.org/10.2991/aebmr.k.200312.053

OECD/Eurostat (2005) Oslo Manual: Guidelines for Collecting and Interpreting Innovation Data, 3rd Edition, The Measurement of Scientific and Technological Activities, OECD Publishing, Paris, https://doi.org/10.1787/9789264013100-en

Petrenko, Y., Vechkinzova, E., Antonov, V. 2019. Transition from the industrial clusters to the smart specialization of the regions in Kazakhstan. Insights into Regional Development, 1(2), 118-128. https://doi.org/10.9770/ird.2019.1.2(3)

Satpayeva, Z. T. (2017), State and Prospects of Development of Kazakhstan Innovative Infrastructure. European Research Studies Journal $\mathrm{XX}(2 \mathrm{~B}), 123-148$.

Schumpeter, J. A. (1934). Theory of economic development. Cambridge: Harvard University Press.

Schumpeter, J. A. (1942). Capitalism, socialism and democracy. New York: Harper.

Semenyuk, O., Abdrashitova, T., Beloussova, E., Nechay, N., Listkov, V., Kurbatova, V., Niyazbekova, S. (2018), The influence of ecology and economic factors on eco-architecture and the design of energy efficient buildings. World Transactions on Engineering and Technology Education, 16(2), 186-192. EID: 2-s2.0-85047534215

Shevyakova, A., Munsh, E., Arystan, M. 2019. Information support for the development of tourism for the diversification of the economy of Kazakhstan, Insights into Regional Development, 1(2), 138-154. https://doi.org/10.9770/ird.2019.1.2(5)

Tereliansky, P. (2016), The variability of fuzzy aggregation methods for partial indicators of quality and the optimal method choiceARPN Journal of Engineering and Applied Sciences. http://www.arpnjournals.org/jeas/research_papers/rp_2016/jeas_0816_4734.pdf 
ENTREPRENEURSHIP AND SUSTAINABILITY ISSUES

ISSN 2345-0282 (online) http://jssidoi.org/jesi/ 2020 Volume 8 Number 2 (December)

http://doi.org/10.9770/jesi.2020.8.2(41)

Make your research more visible, join the Twitter account of ENTREPRENEURSHIP AND SUSTAINABILITY ISSUES: @Entrepr69728810

Tvaronavičienė, M., \& Ślusarczyk, B. (2019). Energy transformation towards sustainability. Energy Transformation Towards Sustainability (pp. 1-333) https://doi.org/10.1016/C2018-0-02510-4 Retrieved from www.scopus.com

Tvaronavičienè, M., Razminienè K. (2017). Towards competitive regional development through clusters: approaches to their performance evaluation. Journal of Competitiveness, 9(4), 133-147. https://doi.org/10.7441/joc.2017.04.09

Vigliarolo, F. (2020). Economic phenomenology: fundamentals, principles and definition. Insights into Regional Development, 2(1), 418429. http://doi.org/10.9770/IRD.2020.2.1(2)

Weidlich, W. (2000). Sociodynamics - a systematic approach to mathematical modeling in the social sciences. Amsterdam: Harwood. Witt, U., \& Zellner, C. (2009). How firm organizations adapt to secure a sustained knowledge transfer. Econ Innov New Technol, 18(7), 647-661.

Xiong, X., Jianmu, Ye, J., Wang, P. 2019. Does the Institutional Environment Affect the Failed Technological Innovation in Firms? Evidence from Listed Companies in China's Pharmaceutical Manufacturing Industry, Transformations In Business \& Economics, 18(1(46)), 60-80.

Ardak NURPEISOVA, PhD student of Financial Academy, Nur-Sultan, Kazakhstan, S.Seifullin Kazakh Agro Technical University, Nur-Sultan, Kazakhstan. Research interests: economics, national economy, innovation.

ORCID ID: https://orcid.org/0000-0002-1245-8313.

Galiya MAUINA, Candidate of Economic Sciences, Associate Professor, Department of economics, Financial Academy, Nur-Sultan, Kazakhstan, S.Seifullin Kazakh Agro Technical University, Zhenis 62, 010000, Nur-Sultan, Kazakhstan. Research interests: economics, national economy, innovation.

ORCID ID: https://orcid.org/0000-0003-3935-6533

Shakizada NIYAZBEKOVA, Doctor of Philosophy PhD, Assistant Professor, Department of Finance and Credit, Moscow Witte University, Moscow, Russia. Research interests: economics, finance, innovation.

ORCID ID: https://orcid.org/0000-0002-3433-9841

Ainur JUMAGALIEVA, Senior Lecturer, S.Seifullin Kazakh Agro Technical University, Nur-Sultan, Kazakhstan. Research interests: information and communication technologies, economics, innovation.

ORCID ID: https://orcid.org/0000-0001-8632-5209.

Aigul ZHOLMUKHANOVA, Candidate of Economic Sciences, Associate Professor, Department of marketing and service, S.Seifullin Kazakh Agro Technical University, Nur-Sultan, Kazakhstan. Research interests: economics, national economy, innovation.

ORCID ID: https://orcid.org/0000-0003-4419-5439

Yuliya TYURINA Doctor of economic sciences, associate professor, Professor of the Financial University under the Government of the Russian Federation, Moscow, Russian Federation

Research interests: economic, finance, management, innovation

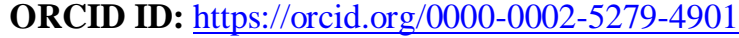




\section{ENTREPRENEURSHIP AND SUSTAINABILITY ISSUES}

ISSN 2345-0282 (online) http://jssidoi.org/jesi/

2020 Volume 8 Number 2 (December)

http://doi.org/10.9770/jesi.2020.8.2(41)

Make your research more visible, join the Twitter account of ENTREPRENEURSHIP AND SUSTAINABILITY ISSUES: @Entrepr69728810

Svetlana MURTUZALIEVA, Docent, Applied Economics. People's Friendship University of Russia (RUDN) of the Russian Federation, Moscow, Miklukho-Maklaya str.6, Plekhanov Russian University of Economics, Moscow, Russia. Research interests: management, economics, finance, innovation

ORCID ID: http://orcid.org/0000-0002-3099-120X

Leila MAISIGOVA, candidate of Economic Sciences, Ingush State University, Magas, Russian Federation. Research interests: economic, finance, management, innovation

ORCID ID: https://orcid.org/0000-0003-2148-4924 